\title{
The Mindset of Russian Poetry and Its Rebellion against Russian History
}

\author{
Olga A. Karlova* \\ Siberian Federal University \\ 79 Svobodny, Krasnoyarsk, 660041, Russia
}

Received 14.09.2015, received in revised form 07.10.2015, accepted 26.12.2015

The paper is focused on studying self-consciousness of Russian poetry and its specific relations to Russian history. The theme choice is determined by celebrating the Year of Literature in Russia and a whole series of anniversaries of the classical poets. To study the correlation between poetic worldview and historic reality of $18^{\text {th }}-20^{\text {th }}$ centuries the author used a kind of "litmus historic scale", based on the concepts of not well-known today Russian scientist, ethnographer, of Valentin A. Moshkov.

Ключевые слова: national literary process, self-identity and mentality of Russian poetry, civil poetry, lyrics, historical cycles, historical declines and rises, concepts of progressivism in literature, art for art only and ahistoric character of poets and poetry.

DOI: 10.17516/1997-1370-2016-9-2-358-373.

Research area: culture studies.

The Year of Literature in Russia does not only set the trend of starting educating journeys in the sacred treasury of the Russian classical literature. It invites us to think over traditions and paradoxes in the national literature process. More so as in 2015 we celebrated a whole series of anniversaries of the classical poets, such as Ivan Dmitriev, Alexander Griboyedov, Kondraty Ryleyev, Afanasy Fet, Ivan Bunin, Alexander Blok, Andrei Bely, Velimir Khlebnikov, Sergey Yesenin, Boris Pasternak, Alexander Tvardovsky, Joseph Brodsky and many others. While looking at this phenomenal list, one can experience a known temptation to learn about the roots and main branches of the "poetic tree" of Russia. In the $18^{\text {th }}$ century Russian "mono literature" changed to author poetic palette, which was partly taken from abroad, partly formed by the enthusiasts of the Russian Enlightenment, partly grown by the folklore studying. But by the end of the century there was already even the pleiad of the authors, whose names were well-known in the literature horizon due to their peculiar lyrical sound and choice of topics. Thus, while turning to the Russian lyrics, it is more correct to review the last three centuries of the Russian poetry. In this very period it formed its own consciousness, specifics of its attitude to the Russian history, to the power in Russia, and to Russia itself.

(c) Siberian Federal University. All rights reserved

* Corresponding author E-mail address: o.a.karlova@yandex.ru 
It is fair to say that "The Tale of Bygone Years" was first and foremost the primary chronicle of the most significant, even sacred events: as it reflected all the plots of Russian uniting and fostering from the positive side and condemned other motives of the historic characters. From this follows that this great old collection of Russian historic and fictional narratives is not only an aggregation of real facts, but rather their ideological selection, systematization and interpretation. In other words, it is nothing but the quasi-history of the Old Russia. If it is true, one can assume that in continuing this tradition Russian poetry of the following centuries pursued the same aim, which is creation on somewhat background of the Russian quasi-history of the new times.

The analysis of the mutual relationships between history and poetry of a certain country logically starts from the historical concepts of this very country and its people. They say, Russian history is quite unpredictable. This joke has a grain of truth, as national historical concepts frequently depended on the ideology and market condition. Some works are overloaded with political bias, the other are charged with futuristic idealism of their creators, while for the objective understanding what history of Russia appears in the context of Russian poetry and how this poetic landscape is correlated with the historic reality of Russia, one needs to use some "litmus historic scale". The tries to find it out led to the concept of Valentin Alexandrovich Moshkov (1852-1922), not wellknown today Russian scientist, ethnographer, General Lieutenant of the Army, full member of the Russian Geographical Society, coordinator of the Society of Archaeology, History and Ethnography in Imperial Kazan University. At the beginning of the $20^{\text {th }}$ century he made an attempt to explain the previous stages in Russian development, which enabled to observe even the farthest horizons - up to the $22^{\text {nd }}$ century. This work was implemented thanks to his travel and research of such peoples as Gagauz people, Scythians, Thracians, Perm people, Karelian people, Mari, Tatars, Mordvinians, Udmurt people, Chuvash, and, of course, Slavs, Russians. To create his own system of historical events the scientist used the findings of a number of sciences and not the mystical "revelations". The main tenet of his theory, to which, however, adhered the ancient European scholars and the ancient Hindus, states: “... all states and all societies, from the largest to the smallest ones in their historical life make a continuous series of turns, which I call the historical cycles". Each cycle, or a historic year, lasts exactly four hundred years and after these four hundred years of their history, people return to where they started, but in a new way. Out of respect for the wisdom of the ancient historians the scientist called each century of the cycle in the same sequence as common: gold, silver, copper and iron. Each of centuries, according to Moshkov, is divided into sections of fifty years, differing from each other by their character. The first halves of century are associated with some decline, and the second halves - with the rise, except for the "iron" century, in which people feel downfall both in the first and in the second halves. "The boundaries between the cycles, centuries and half-centuries for the most part are clearly indicated by somewhat events, the nature of which differs sharply from the previous direction of state life. This makes it possible to determine in the history of each state the dates for the beginning and end of its cycles" ${ }^{2}$. The books of the scientist, first of all "New Theory of the Man's Origin of and His Degeneracy" and "Mechanics of Degeneracy", which set out the anthropological in its essence and civilizational in fact doctrine, received the recognition of his contemporaries. As an outstanding officer in the Russian army, having done much for the Russian history, V.A. Moshkov was awarded the Orders 
of St. Alexander Nevsky, St. Vladimir, St. Anne and St. Stanislaus.

As for our interest in Moshkov's theories, they attract our attention not only by the universal character of historic formulae and reasonableness of judgments, but in the main place by justifiability of his foreseeing. The researcher assumed 812 as the starting point for the first national historic cycle. This was the year of union of the Slav tribes in alliance, which further on was the grounds of old Slav government - Kievan Rus'. So it laid the foundation of the first "golden age" in Russian history: from the decrease to the steady development in the second half of the century. After this there was the "silver age" and then two centuries of the essential decay. The next four centuries started from 1212, this period saw the defeat of Russians beaten by Tatar and Mongol raids, but "after the frightening storm of Baty our country as if had a rest and enjoyed the inner order and silence being ruled by wise Yaroslav Vsevolodovich and Saint Alexander Nevsky"4. This "historic cycle" gave Russia single national identity. As regards the three centuries of literature they belong to the third of the 400-year period, beginning in 1612 and ending in 2012. The first century up to 1712 was the "golden age" of Russian recovery after the Time of Troubles, the establishment of the Romanov Dynasty and especially Aleksey Mikhailovich and the Emperor of All Russia, Peter the Great. The "golden age" was followed by the "silver" one, starting with the downfall of the epoch of Palace Coups, but having seen the rise in the age of Catherine II and the young Alexander I, until the defeat of Napoleon's "motley array of languages". Next in line was the "copper age", which lasted until 1912. The time of Nicholas I was characterized by decline before the defeat of Russia in the Crimean War. The second half of the century showed the rise of power during the reign of Alexander II and Alexander III. Then came the "iron age". In
1910 V.A. Moshkov wrote as such: "So two years later, i.e. in 1912, we enter the Iron Age... What is expressed by this change, we can see in some of the examples of the Iron Age given above. Readers can only observe the reality and verify the validity of historic data judging by the reality". Indeed, he practically anticipated the historical logistics in the century ahead, until 2012. I do not know how to perceive then the famous Tyutchev's phrase that "Russia cannot be understood with the mind alone, No ordinary yardstick can span her greatness..." V.A. Moshkov believed that it is just another poetic myth about Russia, while Russian national spirit can be easily verified by "the mathematics of history", as the described by the scientist cycles are realized in Russia as precisely as possible. However, the Moshkov's historical theory is not as easy in periodization: for example, he calculated the difference in the rise and fall of different groups of the population, and the difference between the cycles of the aristocracy and the common people was - neither more nor less -115 years.

As for instance, in the last 400 years the decline of the "iron age" of aristocracy coincided with the decline of the "copper age" of the common people (1927-1977). One can certainly disagree with V.A. Moshkov: what about the victory in the Great Patriotic War, first flying in space, and construction of the superpower? Still, the logic of the scientist is simple and convincing: the terrible Second World War was the most devastating event for the Russian people; it only would be enough for the whole "iron age". V.A. Moshkov warned: it is necessary to watch the finish of events. In this case, fatal consequences are not only the number of dead Russian people during the war and repression times, but also low compared to other European nations living standards of the bulk of the nation, high mortality and low life expectancy. We need to note therefore 
the loss of cheerfulness: after all events, still the Russian people in the street smile a little, which supports the formed in the Soviet time myth of global gloom of the Russian people, and reduction in personal confidence of a lot of foreigners to Russians. These periods of decline may be accompanied by the illustrious lifting of the national spirit, but it does not change the indisputable fact that the instinct of love is descending, and the instinct of hatred in society is growing. This means that evil prevails over good both in society and in a single man.

So, in the interpretation of V.A. Moshkov historical landscape is obvious to us. What about Russian poetry in this connection? Let us start revising it with reference to the first of poets who celebrated his anniversary this year, Ivan Dmitriev, who was born, according to the classification of V.A. Moshkov, in the midst of the "silver age", namely, in 1760 . Who was Ivan Ivanovich Dmitriev? Minister of Justice of Russia, who did a lot for the development of law in the state, Actual Privy Councilor, who was respected for his dedication to science and morality, the writer of plays, tales, sentimental poems, fables and satires, which received a very restrained assessment from his contemporaries. Nevertheless, later V.A. Zhukovsky called him his teacher in poetry, and after decades the "violent Belinsky" did prove that I.I. Dmitriev was "the converter of the poetic language", at the same time before V.A. Zhukovsky and K.N. Batyushkov his writings were rightly revered to as "exemplary". His later contemporaries respected the poet for his stopping to write in due time, freeing the Olympus for a new poetic pleiad. But he did not give up caring about the glorious Russian history and patriotism: he wrote about it in numerous letters to members of the Union of Welfare, Fyodor Nikolaevich Glinka and Nikolai Ivanovich Gnedich. It is important that many Decembrists, and, above all, Bestuzhev and Ryleyev in their works and letters referred directly to the Dmitriev's motifs and images.

A.S. Pushkin also ranked I.I. Dmitriev to the founding fathers of Russian poetry and called him in a letter "To the Poet friend", along with G.R. Derzhavin and M.V. Lomonosov, "the immortal singer", "honor and glory" of Russia. Moreover, it is critical to clarify how I.I. Dmitriev understood this very "doctrine of the glorious Russian history and patriotism", as his poems were one of the first aspirations of Russian poetry to hold court in the history of Russia. The most popular poem of I.I. Dmitriev was "Yermak". P.A. Vyazemsky found that the poem was full of "a poetic fire", but much more important - "the fire of love for the Fatherland". In contrast, A.S. Pushkin was sharply negative about the poem. This fact may not be recalled, perhaps, it would not be worth mentioning if the story had not had a far-reaching continuing. Kondraty Fyodorovich Ryleyev, another decent poet celebrating his anniversary in 2015, sent to A.S. Pushkin two years later on March 10 1825, the edition of his "Thoughts", where was the thought "Yermak's Death" echoing the Dmitriev's motives. In an accompanying letter K.F. Ryleyev said that he knew the weakness of his creations, feeling that they had even deserved printing. Notwithstanding this, he argued that such heroes of Russian history as Yermak, Matveev, Volynsky, and Godunov are useful for readers and not just children. A.S. Pushkin read all sent poems, praised the poem "Voynarovsky", and as for this matter he wrote once again: "What to say you about "Thoughts"? ... They are all weak in creation and description. They all are one cover: made up of trivia in the description of scenes, the hero's speech and moral. They reveal nothing national, Russian, except for names ${ }^{6}$ ". Why was the Pushkin's reaction to verses, seemingly correct and useful, such derogatory? Why does it sound like a death sentence: "There is nothing 
Russian"? And what is it, a true Russian poetry, according to one of its great founders?

A.S. Pushkin himself was going through the mid-1820s a deep and exciting love affair with history. He was working on "Boris Godunov", deeply studying the works of N.M. Karamzin, referring to W. Shakespeare and W. Scott. At the same time he was thinking to write his own poem about Yermak. What did not appeal to him in Dmitriev's and Ryleyev's reconstructions? Possibly these were excessive moralism, an imitation of European models and deliberate progressivism in the image of a white colonizer? In 1825 he wrote to N.I. Gnedich: "I expect an epic from you. Shadow of Svyatoslav wanders as not be sung upon, you wrote to me once. And what about Vladimir? and Mstislav? and Donskoy? and Yermak? and Pozharsky? The history of the people belongs to the Poet!" "What exactly did he mean by this phrase? In what relationship is the Russian poet with Russian history?

We can dare to assert that the line of patriotic recitations, marching from I.I. Dmitriev to the Decembrists and further to V.G. Belinsky, N.A. Dobrolyubov, N.A. Nekrasov and narodniks, was not perceived by A.S. Pushkin as poetic. It had too little from the laws of poetry, and too much - from social ideology. And the best proof of this is that how Ryleyev's didacticism fit the days of socialist realism, which itself was nothing more than an ideological skeleton in literary garb. This is well illustrated in the famous fragments of the Soviet film "The Tale of the Siberian Land".

Reviews of Dmitriev's and Ryleyev's historical poems started longstanding controversy of A.S. Pushkin with the Decembrists, which only intensified after the uprising and the execution of the leaders of the movement, including K. F. Ryleyev. It is known that the roots of the ideology of the Decembrists lie in the French liberal ideas and contempt for Russia's historical identity. In the minds of "new free masons", who were secretly speculating a new project of the history of Russia, the European myths about freedom were more attractive than the real enlightenment in the period of the late reign of Catherine II, successful Pavlovian reforms of the army and the administration of the country, and even "days of Alexander's great start". But, according to the cyclic theory of V.A. Moshkov, it was in all respects the heyday of Russia, the best period when the rise of the "silver age" of aristocracy coincided with the rise of the "golden age" of the common people. These were 1777-1812. The surge of spirituality, national identity and unity played in the victory over Napoleon almost greater role than military genius of the generals. But any war always has a downside: it abolishes social order, putting the usual established order of life upside down. The officers and the poor noblemen were bankrupt, but by the principles of Tsar Alexander I and his army of the winners did not favor looting, by which any other occupation troops would certainly have improved their financial position. On the other hand, former partisans having felt enough freedom, did not want to go into bondage to their former owners. In addition, the management in the liberated territories was poor, deepening the economic crisis. Although Mikhail Mikhailovich Speransky introduced reforms in legislation, administration and court, which were taken quickly and even ahead of time, that could have promised fast growth of citizens' representation in all spheres of life in Russia, but the damaging European virus was stronger. And, according to A.S. Pushkin, handwritten lampoons concerning the government, outrageous songs, secret societies, more or less bloody and crazy conspiracies, gradually engulfed Russia.

Patriotism of many former students of Tsarskoye Selo Lyceum contributed to moralistic and didactic roots in their poetry, but later it degenerated into anti-government manifestos of Masonic secret societies. In these circumstances, 
the question "What is Poetry?" becomes a key one. I remember that during the Soviet period there were mass Komsomol debates with approximately such questions: here we praise Pushkin, but why did he not join the Decembrists? Why was not he hung, which would have been much more heroic? The official Soviet version was as follows: he strived to join the ranks of the Decembrists, but his friends prevented him from doing so, knowing that everything would end badly. From this version stemmed the thesis about loyalty of A.S. Pushkin to goal of freedom and Decembrist friends ${ }^{8}$, which was reproduced in many of today's literature textbooks. What was A.S. Pushkin really faithful to? What did he defend in bitter disputes with friends, not being afraid to offend them, even "in the depths of the Siberian ores", not fearing to offend the honor of executed fellow writers? The attentive reader will easily understand this from the very poetry of the great master, for example, "Arion", written on July 16,1827 , for the first anniversary of the execution of the Decembrists.

Known to each of the Russians from childhood poem tells the story of the ancient Greek mythological poet and the story of his survival in the storm ${ }^{1}$. But A.S. Pushkin with his romanticism used the legend allegorically. The whole structure of his verse: cadence, rhythm, number of lines in the stanza, the vocabulary shows us two worlds in their opposition. In one world everything is deliberately real, actual, apparent ("a sail", "oars", "a rudder", "the heavy skiff"), in the other world, on the contrary, everything is abstract, ephemeral, secrete and shrouded in mystery ("anthems", "mantle" and if there is "faith", it is careless, if there is a "singer", he is mysterious). The first world is material and historical, it is the world of swimmers and the skipper, it is associated with verbs of only active voice ("moved", "drove", "smashed", "sang"), the second world is the world of the poet, the supreme and sanctified by God through the poetic gift; it is characterized by verbs and lexemes of both active and passive voice and meaning ("sing" - active, "enigmatic" - that is secretly stored, "was thrown" - passive, by someone, something). But the poet needs to demonstrate the real action too: it is most clearly seen in the final lines: "I sing the former anthems, yet, // And dry my mantle, torn and wet, // In beams of sun under a stone". He sings his "former anthems" to Apollo, patron saint of the arts, and his robe of poetry minister he dries it in Apollo's beans. So A.S. Pushkin clearly divides the world of history, the real world and the world of Divine mission of Poetry.

It is well known that by "the skipper" A.S. Pushkin meant his fellow writer K.F. Ryleyev. So in contrast to the "singing Arion" the second key pole of the poem is "silence". "The skipper" "drove the skiff" in the terrible the sea of history in silence, that is betraying the vocation of the true poet, who has only one duty and only one privilege - to sing and serve Poetry. So in the era of romanticism, at the crossroads of the liberal enlightenment and lyric feelings and moods, in Pushkin's verses there was formed the consciousness of Russian poetry.

The use of passive and active voice in Pushkin's lines is particularly interesting. On the one hand, A.S. Pushkin reproaches Decembrists for betrayal to poetic gift and ministry. Being the confidant of their youthful aspirations, he realizes how great is the temptation from a divine oracle, singer and minister of Muses to become a ruler of the historical destinies. A.S. Pushkin himself denies such a fate both for himself and for Russian Poetry. However, the paradox is that the tragic fates, which marked the Decembrists' image, in the end proved to be "cut in the mould" of "poetic romanticism" with punishment, penal servitude, an exile to exotic distant lands, in the "depth of the Siberian ores", and later enlightenment in 
remote Russian provinces. The reality turned out to be the reverse side of the poetic pattern. This romantic model was embodied in the fate of A.S. Pushkin himself. As if there had started a chain reaction of events that poet could not or would not have stopped: dramatic misunderstood in beau monde, fatal confrontation, duel, death. Even the answer to the question of the Emperor: "Where would you have been, sir, if you were on December 14 in St. Petersburg?" A.S. Pushkin gave according to the poetic code of the time: "I would have been in the Senate Square, where my friends were". This answer was demanded by the honor of a gentleman, decency of a friend, and finally "mercy to the man laid low". And here "passively-active voice" of his destiny was vivid again, with "actions" in Poetry and acts in his own life according to the rules of poetry! And so it happened that in his poems, A.S. Pushkin remains the oracle of poetic consciousness in Russia, and in real biography - the victim of this consciousness.

Poetry and the real story between them keep a man with his passions, attachments, resentments and understanding of predestination. Russian poets have always tried their hands in the controversy of life and death in the poetry, where they found the eternal path to their nation, but having tried on the poetic pattern in their own destiny, they inevitably had an early and dramatic death. It is no coincidence that the descriptions of the fatal duel of A.S. Pushkin and M. Yu. Lermontov and their literary descriptions of duels in "Eugene Onegin" and "Death of the Poet" are the same. The love story and the death of another great Russian poet - Alexander Sergeevich Griboyedov also followed the pattern of romantic stories of that time. A. S. Griboyedov was killed by Islamic fanatics in February 1829. The responses of many of his contemporaries were unanimous: his death was instantaneous and perfect. Thus, the death of the poet must necessarily be significant and beautiful. Was it possible to avoid all the poets' deaths near the Chernaya River or in the Caucasus mountains? And is not there deep psychological background in numerous hypotheses about the carefully planned and skillfully carried out killings of the great Russian poets: in duels of the $19^{\text {th }}$ century, or with imitation of suicides, so fashionable in the decadence of the early $20^{\text {th }}$ century?! It is true, that you can easily cover up the Yesenin's murder by his famous lines: "I came to this earth for leave it soon". In 1916, S.A. Yesenin wrote on the topic a cycle of less known verses, one of which was as if the report from the place of his death: "I'll hang myself upon my sleeve, // On a green evening it will happen"2.

Games with death for centuries have remained the most important hypostasis of any poetic destiny, where the death is the flip side of eternity and the path to its mysteries. In his essay "The Keys of Mary"10 S.A. Yesenin admitted that no mystery can be known without the letter to death. In 1932, A.A. Akhmatova wrote about the mystical connection between deaths of N.S. Gumilyov, S.A. Yesenin and V.V. Mayakovsky as a common poetic fate.

The scale of death and eternity determines the scale of judging process concerning not only man, but also history, which has always attracted Russian poets. A.S. Griboyedov, a Russian diplomat, patriot, being already quite well-known author of "Woe from Wit", in 1825 had a thought of writing a drama about the Patriotic War of 1812 and other historic events, connecting the characters from the distant epochs to the political problems of the time, encrusted with thoughts of modern changes and people's rebellions. He admired A.P. Yermolov and expressed sincere respect to Velyaminov, who conquered Kabardia. He was the strong supporter of Russia, declaring the necessity to foster its influence on the East. But in the 
moments of "devoted service to art" he also feels somewhat preceding regularity, which sets the goals of art and cannot be reduced to the citizen's duty only. His works and diaries reveal doubts which A.S. Griboyedov bore about how to see the truth in the quarrel of history and literature. These doubts may well be the reason for his dramatic inner discord. These doubts may well be the reason for irony finding its way through magniloquence of romantic lines from "Woe from Wit". These doubts may well be the reason for his development of the most exalted ideas in mysterious, inviting and secret music writing, but not in literature, where all meanings are revealed in the word.

The romantic laws of the first third of the $19^{\text {th }}$ century were perhaps much stricter that the rules of behavior and public regulation. Probably even history was in some sense more humanistic that the romantic fashion and traditions of the poetic Olympus. However, by the middle of the century the landscape of the Russian reality and Russian literature had markedly changed. The rise of 1862-1912 was characterized by a series of the inner reforms accompanying the reign of Alexander II. The first and the foremost of them was the abolishment of the servitude. The rise showed itself also in the striking growth of the population, in industrial and trade development, in the spread of railways, in increasing the private security of people, in enlightening much wider circles of people that it had been before, in conquering in the Caucuses, Central Asia and new areas in Turkey. This rise was not so high in comparison with other, but this is normal for the "copper age", according to Moshkov's classification. The inner calmness of the country was not disturbed by large uprisals, apart from the short Polish. But there was no the complete tranquility in the intellectual environment, with the press reflecting the fights between the antagonistic parties in the society.
There were also antagonistic parties in the literature environment. The entrepreneurial successes in 1860-70 in Russia caused the ascent of realism like the flourishing economic relations in the Age of Enlightenment brought the fame to Italian novels of everyday life: the books presented the plenty of descriptions of life and manners and separate pictures, then appeared the vast artistic masterpieces, which demonstrated the public types and formed the laws of public life. In these works the ideas of folk enlightenment and moralizing blossomed. The argument of the ways of Russian poetry arose with the renewed vigour. N. A. Nekrasov followed the big words of K.F. Ryleyev, who was sure that the main subject of the poetry is being "useful for society". Strongly opposing the notion "art for art only", he brought the societal necessity to the level of the truth, for "making the man noble and lifted". The Nekrasov's muse was the muse of revenge and sadness, the sister of the peasant girl being flogged. But what is her sadness? Who does she take revenge on? It needs to note that anger, bitterness and irony of the poet do not mark "At the Main Entrance" only, rather they invade all Nekrasov's lyrics: in the pictures of Russian nature, in historical plots; they address the crowd and even severe Russian weather, which is not like the weather only in Nekrasov's verses. His verses produce the smell of "vodka, stables and dust, the characteristic Russian mixture". There is a reasonable question here, if to overcome the inbred love to the Motherland must any Russian poet continuously nurture the spirit of general lack of love to Russia? Is it the only right to acquire the citizen's credo of the poetic word, cast in the formula "The poet in Russia is more than a poet"?

Thewritersofstandingreputation, conserving the altar of the Russian poetry of the second half of the $19^{\text {th }}$ century, are Afanasy Afanas'evich Fet and Fyodor Ivanovich Tyutchev. They had the due 
reputation, as they served Apollo in full devotion and self denial. For A.A. Fet, one of the most progressive Russian landlords, the reformer of the agricultural industry and the essayist writing about economy, the poetry was above everything like "the language of gods". His verses were the captured moments of peace and soul. His manifesto was priceless spiritual and aesthetic Universe of the poetic word. The Fet's tribute to his unromantic time was in the earthly, as if fully embodied in life ideal of Beauty. The nature and world in his verses are seen in enlarged view, as if estranged, through the prism of self-sufficient beauty, blessed by God. Therefore they have the harmony and light, which were typical only of A.S. Pushkin, who was by right called "equinox of Russian poetry". A.A. Fet himself acknowledged that the language of spiritual dissonance would be incomprehensible for him". Fet's poetry does not have any mystery and belongs to mundane world, but is at the same time unpragmatic, bearing the meaning of its existence in itself. It remained unlinked to the very biography of the poet - a noble bastard, a son of two countries, a reformer of the rural Russia. There is a good reason of A.A. Fet's journalism on the agrarian reform and the fatal role of Russian rural communities; on juries and unpractical formation of people called to managing the country; about the dangers of radicalism in universities, etc.; but all these publications do not give away the author of the immortal poetic lines.

Who really did not stain his own poetry with even a hint of pragmatism is F.I. Tyutchev. This diplomat and a frequenter of literary salons could drop a line of lyrical verses, full of charm, at the restaurant and leave this napkin with the tip to the waiter. He sincerely believed that poetry is the need of the heart and spirit, not an occupation for a decent man. That is a tribute to pragmatic time of economic reforms. And so F.I. Tyutchev neither read his poems in the living rooms, nor wrote them into albums, or gave heed to publishing matters, and despite all that he remained in the history of the golden age of Russian literature as the great bulwark of Russian poetry. A.A. Fet called F.I. Tyutchev "the airiest" possible in romanticism epitome of the poet. F.I. Tyutchev was a unique in Russian literature lyricist, as his lines were addressed only to himself. And therefore they unselfishly kept secrets of the Russian poetic self-consciousness and could pass them as baton on. The poet was understood and appreciated by especially true fellow writers. However, being the diplomat who served in different ranks, and for the most part outside of Russia, F.I. Tyutchev never saw the connection between the public service and poetry. And probably he would have been surprised had he known that in Soviet Russia his lyrical poems were not published much until 1966 because of one single fact: as a senior censor of the Ministry of Foreign Affairs F.I. Tyutchev forbade to translate into Russian "The Communist Manifesto", reasonably believing that someone who would have liked to read it, could have read it in German. That, however, it is what really happened. F. I. Tyutchev almost did not use the Russian language in his diplomatic activity abroad and at home, neither of his two wives knew it. Nothing but the mental strain of F.I. Tyutchev, his reflections on life and poetic reminiscences did bear the basis for his lyrical philosophy and effervescence. These were F.I. Tyutchev and A.A. Fet who created in his works the laws of the Golden Age of Russian poetry; lyrical philosophy of the first poet and lyrical sketches of the second poet harbingered famous V.Ya. Bryusov's description of the poet the pale young man with the burning eyes, an individualist, a futurist, a minister of "pure art". Late Tyutchev's lyrics could be viewed as a fragile literary bridge from Pushkin's time to Dostoevsky, built of special and purely Russian state of mind - longing. This Russian longing 
has nothing common with thoughtless spleen and senseless boredom, it is alien to an imported from abroad lightweight veil of lyrical sadness. Russian melancholy is sediment at the bottom of the bottle with an ancient tincture; an age-old sorrow of the people; the primordial truth of the Russian world mixed up of human misery.

The said above in no way contradicts the fact that foreign art has its own library of bitter experiences of discord with the world. N. Pirosmani's true words that art is always an accident are supported by the fact that suffering as folk song genre exists only in Russian folklore. So we cannot be really surprised by Dostoyevsky's advice he gave the novice poet Dmitry Sergeevich Merezhkovsky: "Suffer, you should suffer, young man"!

F.I. Tyutchev's poetic heritage nourished the roots of older Symbolists - Z.N. Gippius, D.S. Merezhkovsky, F.K. Sologub, K.D. Balmont. A.A. Fet's traditions developed with reverence in the holy biblical "acmeism" of N.S. Gumilyov and M.A. Kuzmin; A.A. Akhmatova with her genius overcame acmeism's exotic, while O.E. Mandelstam was keen on tone-painting. Externally negating the influence of predecessors, futurists V.V. Mayakovsky and V.V. Khlebnikov, the creators of the new alphabet of words and meanings, secretly followed this heritage. The harmony of the people's world with nature, the harmony of the human soul were reviewed by A.A. Blok, A. Bely and other representatives of the second generation of symbolists, who in creating a new poetic Bible, based on prophecies of Vladimir Sergeevich Solovyov. They approved a global unity of philosophy, religion, science and art, and the special role in the Russian Orthodox thought of sacred female origin Sofia, wisdom, collegiality, creativity. However, the Silver Age of Russian Poetry in search of its divine mission referred directly to A.S. Pushkin answers. A.A. Blok confirmed this in his direct quote from A.S. Pushkin: "Pushkin! We sang secret freedom following you!" These lines were a citation of the Pushkin's verse "To N.Ya. Plyuskova". At the same time A.A. Blok recalled another Pushkin's verse "To A.F. Orlov", where the poet emphasized his being a poet and not a warrior, so his "secret freedom" was far from the plots of free masons. For A.A. Blok it was important that Pushkin's freedom of thought is different from evolution as it is the knowledge inherent in the poet. A source of freedom is beyond a man and is associated with the essence of art, which is a state of mind, merged with suffering. "This secret freedom, this fad - a word that was uttered the most loudly by A.A. Fet ("Mad Fad of a Singer") is not only personal freedom, but much more than that: it is closely related to the first two deeds, which Apollo requires from the poet. All things described in the verses of Pushkin are a necessary condition for the liberation of harmony". ${ }^{11}$

During the jubilee celebrations in 1924 Sergei Alexandrovich Yesenin came to the steps of the podium at the Pushkin monument. His blond curls stood out in the crowd as well as a bouquet of flowers in his hands. He put the bouquet to the monument's base and read his dedication to Pushkin, which he cited loud and clear as always, waving his arms: "But, doomed to persecution, for a long time I'll sing... // So that my steppe singing would manage to ring out as bronze". ${ }^{12}$

This is another Yesenin's version of the monument to the poet. His prophecy of the earthly period of his life came to nothing in a year, he again met with Pushkin and this meeting was incredible! Before the requiem at the Vagankovsky cemetery a coffin of Yesenin as a worthy successor to the poetic glory was carried around the monument to Pushkin. So the prophecy on the immortality of Yesenin in Russian poetry came true. 
Were there any changes on the verge of another Russian "iron age" in the image of the poet and the idea of poet's mission? Marina Ivanovna Tsvetaeva wrote "POET" about K.D. Balmont, using all four capitals. And it was only because she thought that K.D. Balmont had nothing but the poet in him, he "never sank in worries of the vain world", and he did not know the very notion of nothingness. Here it is the criterion, raised to the rank if not God, but beau-monde. Poets of the emerging "iron age" named by them as the "silver age", even communicated with each other, expressed affection to each other, or rejected each other, only by adhering to cruel ritual of priests and priestesses. Serving the art, the renunciation of life, rejecting the facts, hovering of tragic spirit over the sinful earth - that is the image that gradually became fashionable and often determined the fate of these people, often against their will. It reflected the attitude that was most accurately described by B.L. Pasternak, asking people around the question: "Through the window I'll call to the children: "What millennium is it outside, my dears?"

So in the "silver age" of Russian poetry the manifest of transcendence and ahistoric character of Poet and Poetry became a sacred text, and the ministers of Poetry turned into gods, in "poetic bohemians"... But the most sensitive of them already felt the approaching era of "iron horses" and "iron men". At the turn of the revolution, A.A. Blok wrote one of the most bizarre of his articles "The Collapse of Humanism"13. $\mathrm{He}$ understood humanism as the spirit of individualism of the Renaissance, which was alien both to a "man of the crowd" in early $20^{\text {th }}$ century and to the prevailing bourgeois spirit. Convinced that "in the most significant for mankind century, masses were not the driving force of progress and their voice in the orchestra of world history was not the predominant one", A.A. Blok saw the crisis of humanism in a new force - a mass of people entering the historical arena. What is, according to A.A. Blok, "the music of the masses" and "the music of revolution"? Long before the Spanish philosopher Jose Ortega y Gasset the Russian poet gave a scrupulously accurate historical assessment of the era of the early $20^{\text {th }}$ century: the Russian history saw civilized people losing cultural values and barbaric masses becoming guardians of cultural unconscious. A.A. Blok did not believe in their civilizational possibilities, lamenting the loss of the unity and integrity of the former culture, the lost balance between man and nature, between life and art, between civilization and culture.

By V.A. Moshkov, it is quite logical: the heaviest century of Russian historical cycle is the "iron age", accompanied by the highest social upheavals. Even in 1910, V.A. Moshkov predicted the future constant rise in the price of basic necessities, especially food supplies, the cost of which would increase every year, as well as the breakdown of the financial system and the debt of all sectors of society, the bankruptcy of industrial and commercial enterprises. The result would be hunger, especially among the urban poor people, who, driven to despair, in search of those responsible for their misfortune would turn their attention to the government and the wealthy classes. Riots promised to be extremely brutal, with beating and destruction of wealthy and powerful people. However, the most serious consequence for the culture of the people, in his opinion, would be the degradation of the "pole of love" and its change, through indifference and apathy, to the "pole of hatred". The weakening of any nation begins with the weakening of ties with its own government and then with the homeland, and finally, with their fellow citizens and their own family. The revolution was the peak of this biblical tragedy of humanity, when a brother kills another brother, a son opposes his father, and a mother sacrifices her child to the idea. 
The "iron age" intrudes into the rhythms of poetry by S.A. Yesenin, V.V. Mayakovsky, and B.L. Pasternak. It transformed even a person in accordance with the most well-known metaphor of the proletarian poet Nikolay Tikhonov: "If you make nails from these people, these nails would be the strongest ones in the world!" Where is the source of "poetic ore" for these iron men of the world revolution? It all started in the early 1930s with the "reforging" humanism: the main feature of Soviet literature became the brave "proletarian humanism", firmly involved in the hatred. The second remarkable facet of "proletarian humanism" is joy. "Proletkult" demanded to release literature from suffering, to banish "accounts of human misery" from art, and at the same time to ban the pre-revolutionary writers and books. Anton Makarenko was convinced: "We have learned to be happy in the highest sense, when one can be proud of his happiness. It belongs only to us - sincere and direct members of a classless society". ${ }^{14}$ Thus, the joy and pride as the foundation of Soviet poetry rest on social chosenness, and from it comes the only virtue, literally incompatible with any moral doubts and aesthetic experiences loyalty to the proletarian idea.

The temptation of poets was enormous. V.V. Mayakovsky was among the first to give in; once he was terribly touching in his early poetic yellow sweater, rebelling against the laws of the crowd. The next day he dreamt of that the crowd, no matter what, loving or indignant, would pick up his cry, his poetic word as "goldborn comet" in the struggle against those who have "weak eyes", in direct combat with the enemy. From the poet of "clouds, stars and flutespine" V.V. Mayakovsky quickly transformed into a revolutionary Homer. This race would involve also B.L. Pasternak. In 1934, at the First Congress of Soviet Writers, he was declared number one poet by N.I. Bukharin, but a year later Stalin would return V.V. Mayakovsky to the top of Mount Olympus of Soviet poetry.

The drama of the situation is that both poets had a bright talent and originality. In terms of literary retrospectives it is even strange to compare, for example, the power of large-scale metaphors by V.V. Mayakovsky, who stood for re-appropriating the names of the world, with B.L. Pasternak, who dipped into the secret codes and suggestive lyrical poetry. Both were in a vise between the intuitive sense of their own poetic way, on the one hand, and fits of jealousy, tempting proximity to power, the desire of universal acceptance, on the other hand. And that competition for public recognition left an imprint on their poetry, which by feel turned into "not all the way poetry". Skeptical M.I. Tsvetaeva believed that neither the one nor the other was capable of "singing" and that the place of Blok and Yesenin was vacant in Russia.

Speaking of Russian poetry, we cannot neglect the Russian diaspora. "Blok and Yesenin's place" in it was claimed for by several poets, and among the first - the person celebrating his anniversary this year, the Nobel Prize Laureate in Literature Ivan Alexeevich Bunin. The main counterpoint of his poems is love and death. The main topic of the poet is the loneliness. The main context of his poetry is sounding silence. Bunin's Silence is like Arion's song by A.S. Pushkin. This silence suggests forest noises, rolling cries of cranes, all other natural sounds that share the loneliness of the poet, giving him the answers to unspoken questions. The state of "boundless silence and deep stillness" is a true poetic being without others, without the noise of profane existence; it is a prerequisite of contemplation of beauty and truth. Two temples - the temple of Nature with its natural sounds and a ringing of Orthodox Church bells are two ways of climbing in the heavenly world. And comprehension of 
the truth of life on both these paths is verified by death.

In Soviet Russia the crisis of universal humanism and triumph of socialist realism strengthened "more than poetry" tradition. Even the most talented poets of not only the proletarian origin, but also from the generation of 1960s did not escape the fate of mandatory supporting this trend. 1960s entered the history of Soviet Russia as a period of "The Khrushchev Thaw"; these years brought a certain rehabilitation of humanism as the principle of people's relationships, which resulted in the legal rehabilitation of the repressed, in works of art, and even in the appearance of an entire galaxy of Soviet artists, which would later be called "the Sixtiers". But the thaw is not the summer, and in fact this period was rather a dream about humanity than the consistent implementation of this principle in the Soviet reality. According to the Moshkov's system of historical coordinates in the $20^{\text {th }}$ century a special place belongs to the year of 1962 as the "last year of history". A couple of decades ago, this prediction would have caused only bewildering, but at the beginning of the $21^{\text {st }}$ century secret archives opened, and today we know that in 1962 because of the "Cuban Missile Crisis" (Soviet deployment of missiles in Cuba and the response of the US administration) the world was indeed in a stone's throw from the world-wide catastrophe. Russia focused on external threats, so it could not marshal serious force on the domestic front.

In the poem "Distance After Distance", created in the years preceding the Thaw, another current poet Alexander Trifonovich Tvardovsky, who also celebrated his anniversary this year, gave an entire stanza to "the place of the poet in working order": "I was born into the world to live and not for the good front page". Even this last opposition for A.T. Tvardovsky with his poetic destiny and life biography is evidence of an unprecedented creative freedom. This is the "high road" of Soviet poetry. Soviet poets in 1970-80s gathered stadiums. Ye.A. Yevtushenko, R.I. Rozhdestvensky, A.A. Voznesensky, B. Akhmadullina... Each of them, perhaps, for the first time during three centuries of Russian literature, knew what the fame is. Multimillion of people felt love for them. Lovers again and again listened to their hackneyed tape cassettes with songs on poems written by R.I. Rozhdestvensky and A.A. Voznesensky. Along with typically Soviet poems like "To Longjumeau" and "Bratsk Hydroelectric Power Station" there were such poignant lines: "We are a long echo of each other..." or fragile requests: "Give me the secondclass ticket to childhood!" In verses of Soviet poets their rhymed journalism and poetry were so contrary to each other that often converged in mortal combat. And one should not be surprised that the poets' personal fate was coerced and marked with the total trouble, despite the apparent success with readers and constant being in favour among authorities. But at the same time, from the depths of "interior", "hempen and homespun" country, the country of physicists and poets, heroes of labor and homeless people, athletes, champions and black marketeers selling "acid washed" jeans and Baltic bubble gum, there appeared something completely new, which is wild and unruly poetry, calling itself an amateur song. And cassette recorders across the country suddenly started to sigh silently with B.Sh. Okudzhava, listen to the mountain echo in Yu.I. Vizbor's songs, wheeze hysterically along to V.S. Vysotsky's songs. All songs possessed sincerity, rebellion, confessional character like a breakthrough.

"Oh, how much light is given at night by ink merging with darkness..." - this verse by Joseph Alexandrovich Brodsky, the poet of "white and black contrast", the border branch of the Russian poetry seems already very nonRussian, except for the language. Brilliant voice of "poetry in general" - the poetry outside of 
Russia... Is really this poet also organic for the tree of Russian poetry? Let us look for a special mark on the clock of history. V.A. Moshkov sees as essence of national decline a gradual break of all connections, loosening the ties that bind the nation, government and people, the poet and his homeland. This process is inevitable, especially during the last decades of yet another "iron age". But, thanks God, it will not last forever. So, History also plays with a poet in symbols and meanings. The most favorite grammatical prefix of J.A. Brodsky was "ot-" (meaning departure, absence, imprint, separation, rejection, despair...) According to S.A. Lurie, the most organic state of J.A. Brodsky is detachment, alienation from dependence and attachment, finite and therefore doomed things and feelings. Researchers assert that the Russian rhythms in Brodsky's verses exist only in the Russian accent in his English speech, in the sonic line, reproducing the repetitive clatter of the wheels of the train crossing Russia, and in the shortened verse, as if written in a communal room or Norenskaya hut. Beloved Brodsky's belief was considering a language a form of patriotism, with the Russian language being the "mask of the soul" of Russia. And subsequently his patriotism is expressed in wonderful poems in Russian. They occasionally resemble sound of bells and church singing. And they have 346 repetitions of the words "Motherland", "country", "home", "Russia" in contrast to only 5 references of America.

Relations of the poet with Russia are complex and delicate, and ironic, critical and nostalgic with its history. J.A. Brodsky is the Russian poet with original "dislike for the Motherland", a careful recognition of the value of the element of "uncivilized provincial Russian-ness" and with the instincts of the "globally-minded man".

Let us open the pages of literary criticism of 1990s to make sure: following after J.A. Brodsky
Russia seemed to run out of great poetic names, claiming the Nobel Prize. The present poets lack the scale of talent and the scale of ideological confrontation. New poetic landscape of the $21^{\text {st }}$ century is at the stage of formation. In literary criticism today there is a lot of talk about "sleeping branch of the Russian poetry" - the new generation of Russian poets. What will happen when it "wakes up"? The question is not idle. But, according to V.A. Moshkov, to imagine the future we must carefully look into the past.

What we did, overlooking the Russian poetic landscape during three centuries. And it is now absolutely clear that Russian poetry is a special invented history of Russia, and this fictional and suffering quasi-history has a strange feature - it can influence the real history.

Recall the final Pushkin's lines "Exegi Monumentum"15: neither to passion, nor to the political sail, but "To God and his commands pay Thou good heed, O Muse"s. And here it is important where and how the knowledge of the true God command was taken. In 1826, in the poem "To The Poet" A.S. Pushkin created his manifesto of freedom of the poet: the feeling of being a king, on a "free road" with "free spirit", experiencing loneliness in the world. In "Ode to Liberty" A.S. Pushkin wrote about law of God ${ }^{16}$ : "But woe betide the commonweal // Where it is blithely slumbering, // Where Law itself is forced to kneel // Before the Masses..."4 So Pushkin equals all power: democratic and autocratic; of the governments and of peoples, etc. before the judgment of God. And the Poet for A.S. Pushkin is the voice of God, elevating him above History. For what? "For inspiration, sweet sounds and prayers".

So, the continuation of the verse is very symbolic, as it appeals to the creative descendants of A.S. Pushkin: "To God and his commands pay Thou good heed, O Muse. // To praise and slander both be nonchalant and cool”. And especially to 
M.Yu. Lermontov, whose offend for his generation led the poet to theomachy, preventing his soar over history; to the poets of the early $20^{\text {th }}$ century and the Soviet period, one of whom sought in art the bohemian worship, the other looked for the mercy of those in power. A.S. Pushkin completes the final lines of "Exegi Monumentum" by the words: "Demand no laureate's wreath, think nothing of abuse, // And never argue with a fool". These lines are recalling primarily of A.A. Fet and F.I. Tyutchev, the poets of poetic timelessness. But they are also an eulogy to A.A. Blok, A.A. Akhmatova, S.A. Yesenin, B.L. Pasternak , V.S. Vysotsky and J.A. Brodsky, - almost the entire poetic $20^{\text {th }}$ century.

Does this mean that "Exegi Monumentum" by A.S. Pushkin is a poet's formula of the Law of Poet's belonging to History and also a project of rewriting national history according to the set poetic rules?

\footnotetext{
The English translation was made by Y. Bonver. See in detail: http://www.poetryloverspage.com/poets/pushkin/arion. html

2 The English translation was made by A.S. Vagapov. See in detail: http://samlib.ru/w/wagapow_a/yesen.shtml\#Im_tired_ of_living

3 Translation made by A.Z. Foreman. See in detail: http://poemsintranslation.blogspot.ru/2013/10/pushkin-exegi-monumentum-from-russian.html

4 Translation made by A.Z. Foreman. See in detail: http://poemsintranslation.blogspot.ru/2015/07/pushkin-ode-to-liberty-
} from-russian.html

\section{References}

Azarova, K.M. (1995). Posobie po Russkoi literature XIX veka [Textbook on Russian literature of XIX century]. M., 144.

Blok, A.A. (1962). O naznachenii poeta [On vocation of the poet]. In Sobranie soch. v 8 tomakh [Collected Works in 8 Vols]. Moscow-Leningrad, Khudozhestvennaia Literatura, 6,166.

Makarenko, A. (1956). Schast'e [Happiness]. Russkie pisateli o literaturnom trude [Russian writers on literary work]. In Sobranie soch. v 4 tomakh [Collected Works in 4 Vols]. L., Sov. Pisatel', 4, $758-761$.

Moshkov, V.A. Mekhanika vyrozhdeniia [Mechanics of Degeneracy], 80 p, available at: velesovasloboda. vho.org P. 21.

Moshkov, V.A. Mekhanika vyrozhdeniia [Mechanics of Degeneracy], 80 p, available at: velesovasloboda. vho.org 22.

Moshkov, V.A.(1907). Novaia teoriia proiskhozhdeniia chelovekaiego vyrozhdeniia, sostavlennaia po dannym zoologii, geologii, arkheologii, antropologii, etnografii, istorii i statistiki [New Theory of the Man's Origin of and His Degeneracy, composed by data of zoology, geology, archaeology, history and statistics]. Warsaw, Publishing House of Provincial Government,.186 p, available at: e-reading.by

Moshkov, V.A. Mekhanika vyrozhdeniia [Mechanics of Degeneracy], 59.

Pushkin, A.S. (1977). Ia pamiatnik sebe vozdvig nerukotvorny [Exegi Monumentum]. In Sobranie soch. v 10 tomakh [Collected Works in 10 Vols], 2, 385.

Pushkin, A.S. (1977). Ia pamiatnik sebe vozdvig nerukotvorny [Exegi Monumentum]. In Sobranie soch. v 10 tomakh [Collected Works in 10 Vols], 2, 46.

Pushkin, A.S. (1977). To K.F. Ryleyev (May 1825). In Sobranie soch. V 10 tomakh [Collected Works in 10 Vols]. M., Khudozhestvennaia Literatura, 9, 148.

Pushkin, A.S. (1977). To N.I. Gnedich (February 23, 1825). In Sobranie soch. V 10 tomakh [Collected Works in 10 Vols]. M., Khudozhestvennaia Literatura, 9, 130. 
Yesenin, S.A. (1977). Sobranie soch. v 3 tomakh [Collected Works in 3 Vols]. M., Pravda, 3, 139-162.

Yesenin, S.A. (1977). To Pushkin. In Sobranie soch. v 3 tomakh [Collected Works in 3 Vols],1, 205.

In Collected Works in 8 Vols, 6, 93-115.

\section{Ментальность русской поэзии \\ и ее бунт против русской истории}

О.А. Карлова

Сибирский федеральный университет

Россия, 660041, Красноярск, пр. Свободный, 79

Статья посвящена исследованию самосознания русской поэзии и спещифики ее отношения $к$ российской истории. Ее актуальность связана не только с Годом литературы в России, но и с чередой юбилеев в 2015 году многих классиков русской поэзии. За основу своеобразного «лакмусового исторического ландшафта» России при изучении корреляции поэтической картины с исторической реальностью ХVIII-XX вв., взяты труды выдающегося российского ученого-этнографа Валентина Мошкова, преданного в советское время незаслуженному забвению.

Ключевые слова: начиональный литературный процесс, самосознание и ментальность русской поэзии, гражданская поэзия, лирика, исторические иикль, упадки и подъемы в истории, концепции прогрессизма в литературе, «искусства для искусства» и внеисторичности поэта и поэзии.

Научная специальность: 24.00.00 - культурология. 